\title{
Margaret Dix, Charles Hallpike and the 'Lagerungs' Manoeuvre
}

\author{
Margaret Dix, Charles Hallpike e a Manobra 'Lagerungs' \\ Péricles Maranhão-Filho', Raj Nandi², Eliana T. Maranhão ${ }^{3}$
}

\begin{abstract}
The main objective of this manuscript is to describe some personal and professional aspects of two outstanding researchers and pioneers in neuro-otology. Among other achievements, Margaret Ruth Dix, and Charles Skinner Hallpike, designed the most-used provocative test for positional nystagmus for the diagnosis of lithiasis in the vestibular posterior semicircular canal.
\end{abstract}

Keywords: Margaret R. Dix; Charles S. Hallpike; vestibulolithiasis

\section{RESUMO}

O principal objetivo desse manuscrito diz respeito a alguns aspectos pessoais e profissionais de dois excelentes pesquisadores e pioneiros da neuro-otologia. Entre outras descrições, Margaret Ruth Dix e Charles Skinner Hallpike descreveram o teste provocativo mais utilizado de nistagmo posicional para o diagnóstico de litíase no canal semicircular posterior do sistema vestibular.

Palavras-chave: Margaret R. Dix; Charles S. Hallpike; litíase vestibular.

In 1945, at the end of the Second World War, Dr. Margaret Dix joined the staff of the Otological Research Unit at the National Hospital, Queen Square, London, UK. Seven years later, Dr. Dix, together with the head of service, Dr. Charles S. Hallpike described the clinical bedside test, aimed to provide an immediate diagnosis of the presence of solid particles in the endolymph of the posterior vestibular semicircular canal. We describe the experiences of these two researchers who have enshrined their names in the history of modern neuro-otology.

\section{MARGARET DIX}

Margaret Ruth Dix (Figure 1), the daughter of a Clerk in Holy Orders (a Shropshire rector), was born in 1902 and grew up with parsonage discipline of kindly good manners and a sense of responsibility. Little is known about her early school years. She studied medicine in London, at the Royal Free Hospital, School of Medicine for Women. When asked why she chose a medical career, she would reply: "Because a woman cannot be a clergyman"1.

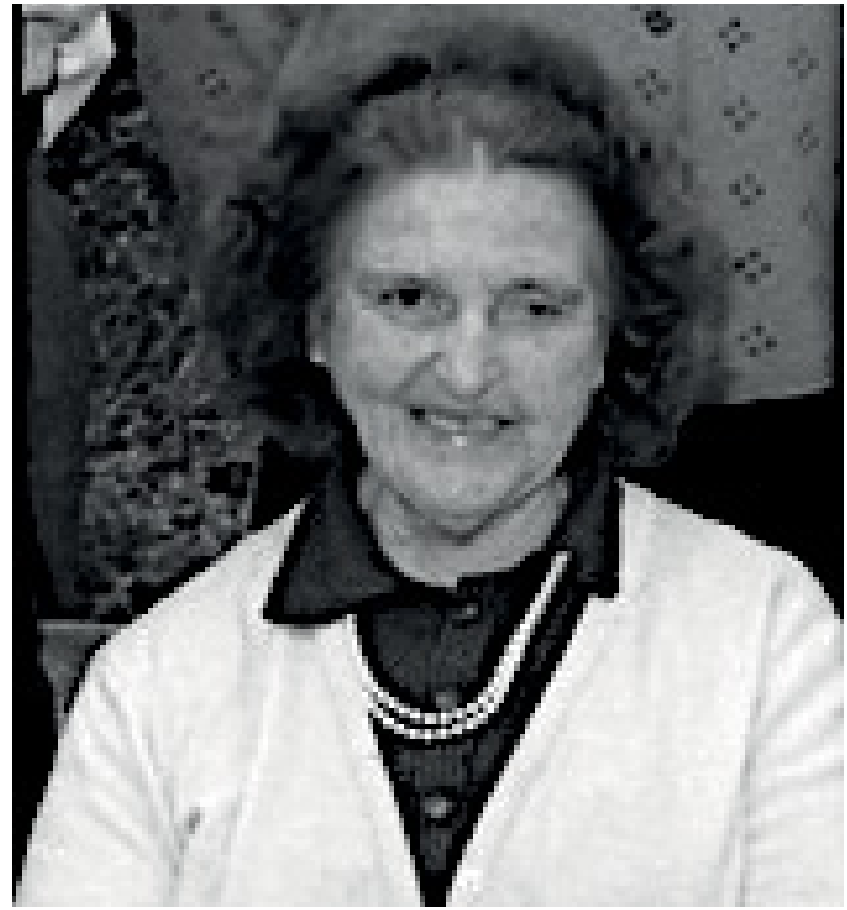

Queen Square Archives authorized.

Figure 1. Margaret Ruth Dix.

1 Universidade Federal do Rio de Janeiro, Hospital Universitário Clementino Fraga Filho, Departamento de Clínica Médica, Serviço de Neurologia, Rio de Janeiro RJ, Brasil;

${ }^{2}$ Royal National Throat Nose and Ear Hospital, Consultant Physician specializing in Audiovestibular Medicine, London, United Kingdom.

${ }^{3}$ Instituto Nacional de Câncer ( $\mathrm{HCl}$ ), Serviço de Fisioterapia, Rio de Janeiro RJ, Brasil.

Correspondence: Péricles Maranhão-Filho;Av. Prefeito Dulcídio Cardoso 1680/1802; 22620-311 Rio de Janeiro RJ, Brasil; E-mail: pmaranhaofilho@gmail.com Conflict of interest: There is no conflict of interest to declare.

Received 01 November 2017; Received in final form 27 March 2018; Accepted 05 June 2018. 
Before the war, Margaret was outstandingly beautiful, with a lovely complexion and eyes that could truly be described as sparkling-a young woman whose enjoyment of life was evidenced by her whole bearing.

In 1937, she qualified and was appointed as House Surgeon to Sir Douglas McLaggan (among others), who recognized her competence and allowed her to perform tonsillectomy surgeries, which appeared deceptively simple in her hands. During the war in 1940, in a German air-raid "Blitzkrieg", a tragic accident changed the course of her life when she was hit by a window and her face was unrecognizably mutilated by multiple deep lacerations. One eye was badly damaged and an eardrum torn. Although treated by the eminent pioneer in plastic surgery, Sir Archibald McIndoe, the scars remained for the rest of her life. Fragments of glass lodged in her eyes, preventing her from continuing her career as a surgeon ${ }^{1}$. Reconstruction of her face and rehabilitation were prolonged and a painful process, and pieces of glass were extruded from time to time.

Her own experience and that of her severely deaf mother made her sensitive to the needs of patients. In 1945, she joined the staff of the Medical Research Council Otological Research Unit at the National Hospital under the direction of Dr. C.S. Hallpike, carrying out research on deafness in exservicemen. This led her on to a career in neuro-otology, investigating diseases of the inner ear and its central nervous pathways, and pioneering what was initially a new branch of medicine at that time.

She published over 100 articles on a wide range of auditory, vestibular, and neurological conditions, and received international recognition and numerous prizes for her work ${ }^{2}$.

Margaret Dix was appointed Honorary Consultant to the National Hospital in 1965 and worked there until her retirement in 1976 as a locum consultant until the age 70. In her spare time, she was an accomplished painter, and enjoyed writing poetry ${ }^{2}$. She died on December 9, 1991, at the aged of 89.

\section{CHARLES HALLPIKE}

Charles Skinner Hallpike (Figure 2), was born in Murree, India on July 19, 1900. At three years of age, his family came to London, and he was educated at St Paul's School, graduating in $1919^{3}$.

The young Charles was an excellent athlete, but when he has 12 years old, his life was changed due to an aseptic necrosis of the femoral head (Legg-Calve-Perthes disease) after a minor trauma. This condition forced him to walk with a crutch due an increasingly painful osteoarthritis of the hip ${ }^{4}$.

Hallpike became interested in studying temporal bone pathology while he was a research fellow at the Ferens Institute of Otology in London in the early $1930 \mathrm{~s}^{4,5}$.

He published 241 papers. The most important were on Ménière’s disease, vestibular function, optokinetics, caloric nystagmus, and inner ear degeneration ${ }^{5}$.

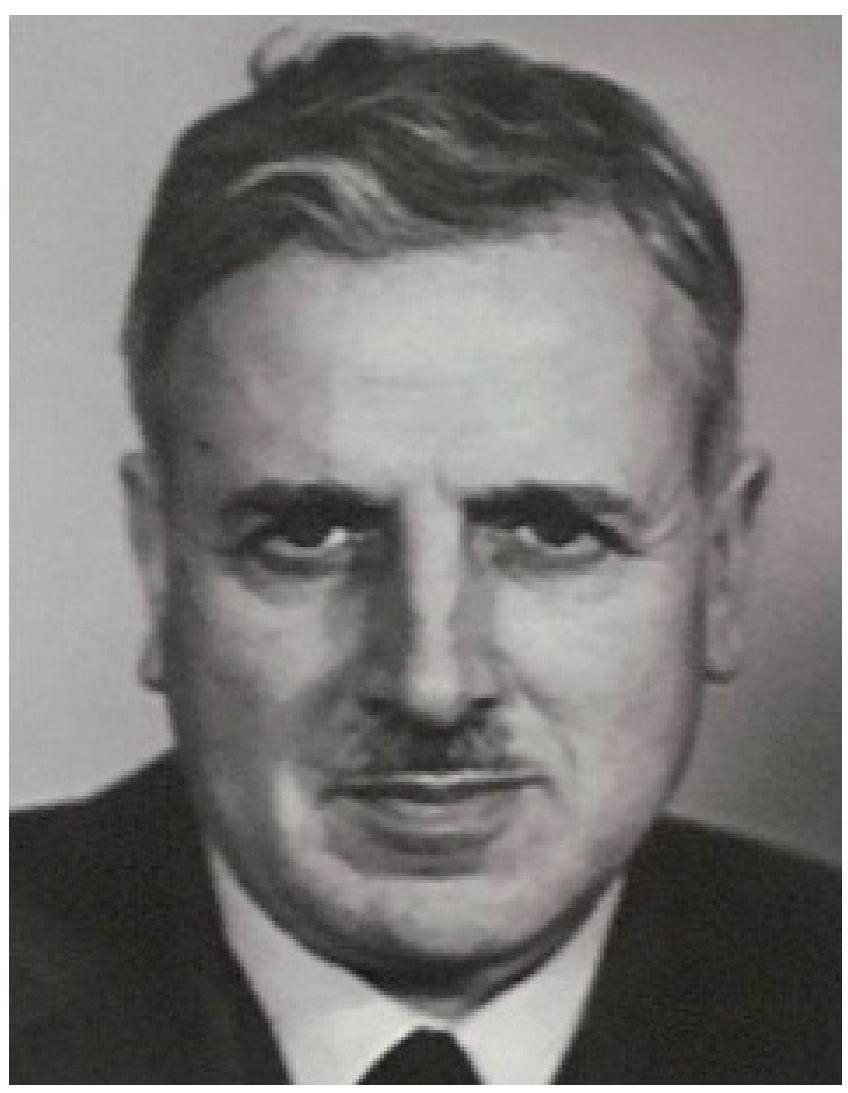

Queen Square Archives authorized.

Figure 2. Charles Skinner Hallpike (in 1956).

In July 1935, he married Barbara Lee Anderson ${ }^{5}$ and had two sons and one daughter. The elder son, Jeremy, who was born in 1936, also studied medicine, and became a consultant neurologist in Australia. The younger son, Timothy, became an officer in the Royal Navy, and the daughter, Janet, took an honors degree in English and Theology in Cambridge, but died in $1966^{3}$.

In 1942, Hallpike joined the scientific staff of the Medical Research Council at the National Hospital, Queen Square, London, where his power of organization and administration resulted in his appointment as Aural Physician and Director of a newly-established Otological Research Unit at the hospital ${ }^{6}$.

He began his career in neuro-otology thoroughly reading the works of the Austrian Nobel Prize winner, Robert Bárány. He was well grounded in the German literature and frequently quoted Bárány in his publications. Interestingly, there were remarkable parallels in the careers and lives of Hallpike and Bárány. Both had physical disabilities in their legs from childhood that limited their physical activity throughout life. Both had dramatic early successes that propelled their academic career-Bárány with the caloric test and Hallpike with the pathology of Ménière's disease. They were clinicians first, researchers second, and much of their work was directed toward developing reliable clinical diagnostic tests. Both were extreme perfectionists and had a fascination with the central nervous system. Both (mistakenly) 
believed that the cause of positional nystagmus was an otolithic disease. Unfortunately, both had multiple strokes at the end of their lives ${ }^{4}$.

According to Margaret Dix, Hallpike was quick to recognize and appreciate good work, intolerant of fools but unfailing in giving due credit to his co-workers. His special interest was in the relationship of experimental observation to clinical problems ${ }^{6}$.

In his 70s, Hallpike suffered several transient ischemic attacks and had to give up driving in 1976, after having had some minor accidents.

After his retirement, he enjoyed gardening and won prizes locally for his roses. He died in Southampton on the September 26, 1979, at the age of 79.

\section{THE ‘LAGERUNGS’ MANOEUVRE}

Margaret Dix and Charles Hallpike produced vast coauthored otology and neuro-otological literature ${ }^{7.8}$. In 1952, they published a 13-page manuscript: The Pathology, Symptomatology and Diagnosis of Certain Common Disorders of the Vestibular System ${ }^{9}$, which became a landmark in contemporary neuro-otology. They carried out an excellent study of symptoms and natural history of the three most common peripheral vertigo diseases: Ménière's disease, vestibular neuritis, and benign paroxysmal positional nystagmus. For the latter, 100 patients were studied, and the authors described the 'Lagerungs' manoeuvre ${ }^{10}$ in detail (Figure 3).
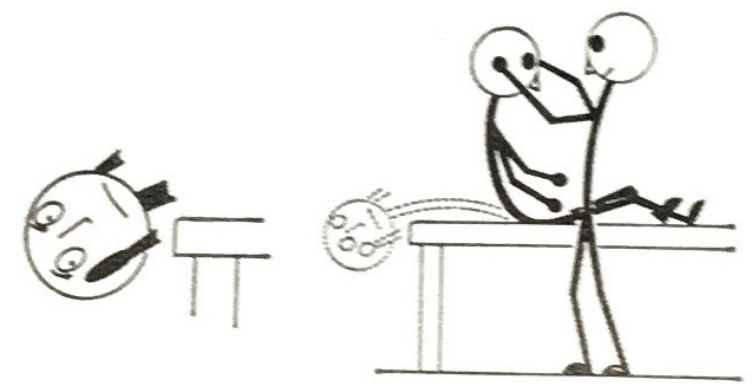

Figure 3. The critical head position for positional nystagmus of the benign paroxysmal type. The 'Lagerungs manoeuvre ${ }^{9,10}$. Queen Square Archives authorized.

Hallpike's final comments on positional nystagmus were presented at a meeting of the Bárány Society in London, when he was 77 years old ${ }^{4}$. Since Dix and Hallpike's description, this has become the most-used test in the diagnosis of posterior semicircular canal lithiasis, with the sensitivity and specificity estimated at $79 \%$ and $75 \%$, respectively.

\section{Acknowledgment}

To Sandra Bamborough. Information Assistant, Queen Square Library and Archive UCL Institute of Neurology \& The National Hospital for Neurology \& Neurosurgery (UCLH), who provided us with the material needed for this manuscript.

\section{References}

\footnotetext{
1. Bowden REM. Obituary Margaret Dix. Queen Square Archives of the National Hospital for Neurology \& Neurosurgery and the UCL Institute of Neurology. Annual Report. 1991-1992. p. 9.

2. Hood JD. Obituary Margaret Dix. Queen Square Archives of the National Hospital for Neurology \& Neurosurgery and the UCL Institute of Neurology. Annual Report. 1991-1992. p. 8.

3. R Hinchcliffe. Charles Skinner Hallpike. Br Med J. 1979;2:1444.

4. Baloh RW. Charles Skinner Hallpike and the beginnings of neurotology. Neurology. 2000;54:2138-46.

5. Whitteridge D., Merton P. A. Charles Skinner Hallpike. Biogr Mem Fellows RI Soc. 1984;30:281-95.
}

6. Dix MR. Obituaries. C.S. Hallpike. Nature 1980;284:386.

7. Dix MR, Hallpike CS. The Peep-show. Br Med J. 1947;2(4531):719-23.

8. Dix MR, Hallpike CS. further observations upon the diagnosis of deafness in young children. Br Med J. 1952;(i):235-44.

9. Dix MR, Hallpike CS. The pathology, symptomatology and diagnosis of certain common disorders of the vestibular system. Proc R Soc Med. 1952;45:341-54.

10. Hallpike CS. Positional nystagmus, and some introductory remarks. In: Hoode JD, editor. Vestibular mechanisms in health and disease. London: Academic Press.; 1978. p. 167-77. 